\title{
Human Paragonimiasis in Africa
}

\author{
${ }^{1,2}{ }^{\prime}$ 'Da A. Aka, ${ }^{1}$ Koffi Adoubryn, ${ }^{2}$ Daniel Rondelaud and ${ }^{2}$ Gilles Dreyfuss \\ ${ }^{1}$ Laboratory of Parasitology-Mycology, Faculty of Medicine, BP V 166 Abidjan, Ivory Coast \\ ${ }^{2}$ UPRES EA $n^{\circ} 3174$ / USC INRA, Faculties of Medicine and Pharmacy, 87025 Limoges, France \\ Reprint requests to: Dr N. A Aka, Laboratory of Parasitology-Mycology, Faculty of Medicine, BP V 166 Abidjan, \\ Ivory Coast. E-mail: akadavid2000@yahoo.fr
}

\begin{abstract}
An up-to-date review on human paragonimiasis in Africa was carried out to determine the current geographical distribution of human cases and analyze the animal reservoir, snails and crustaceans which intervene in the local life cycle of Paragonimus species. Two countries, i.e., Cameroon and Nigeria, were mainly affected by this disease, while the distribution of human cases in the other eight states of the intertropical zone was scattered. Infected patients were currently few in number and two Paragonimus species: $P$. africanus and $P$. uterobilateralis, were found. The animal reservoir is mainly constituted by crab-eating mammals. The identity of the host snail remains doubtful and was either a prosobranch, or a land snail. Seven crab species belonging to Callinectes, Liberonautes and Sudanonautes genera are able to harbour paragonimid metacercariae. Due to the current low prevalence of human paragonimiasis recorded in Africa and the high cost of wide-scale screenings for this disease, training of technicians in anti-tuberculosis centers would be the most realistic attitude to detect mycobacteria and/or Paragonimus eggs during the same sputum examination.
\end{abstract}

Key words: Paragonimus spp., Africa, human paragonimiasis, intermediate hosts, tuberculosis

\begin{abstract}
Résumé
Une revue sur la paragonimose en Afrique a été réalisée pour déterminer la distribution géographique actuelle des cas humains et analyser le réservoir animal, les mollusques et les crustacés qui interviennent dans le cycle local des espèces de Paragonimus. Deux pays, à savoir le Cameroun et le Nigeria, sont principalement affectés par cette maladie tandis que la répartition des cas humains dans les huit autres états de la zone intertropicale est dispersée. Les patients parasités sont actuellement peu nombreux et deux espèces de Paragonimus: $P$. africanus et $P$. uterobilateralis, ont été identifiées. Le réservoir animal est principalement constitué par des mammifères mangeurs de crabes. L'identité du mollusque hôte reste douteuse et se rapporte à un prosobranche ou à un mollusque terrestre. Sept espèces de crabes appartenant aux genres Callinectes, Liberonautes et Sudanonautes sont capables d'héberger des métacercaires de Paragonimus. En raison de la faible prévalence actuelle de la paragonimose humaine en Afrique et du coût élevé du dépistage à grande échelle pour cette maladie, la formation des techniciens dans les centres anti-tuberculeux serait l'attitude la plus réaliste pour détecter simultanément les mycobactéries ou les œufs de Paragonimus, lors de l'examen du même crachat.
\end{abstract}

Mots clés: Paragonimus sp., Afrique, hôtes intermédiaires, paragonimose humaine, tuberculose

\section{Introduction}

Pulmonary distomatosis, also known as paragonimiasis, is an anthropozoonosis essentially 
accidental contamination, or the fact of at-risk eating habits (consumption of freshwater crustaceans infected with Paragonimus metacercariae and inadequately cooked). In the world, two hundred million people would be exposed to this parasitosis and twenty million persons would be infected. ${ }^{2}$ Most human cases have been reported on the Asian continent. In Africa, endemic foci were reported in about ten countries, mainly around the Guinean Gulf and in the central part of the continent. Two species of Paragonimus are described on this continent ${ }^{3}$ and other two species were suspected. ${ }^{4}$

In spite of some reports on this parasitosis in Africa, three points currently pose a problem. The first concerns the total number of patients affected by this disease, as it cannot be specified for the following three reasons: i) tuberculosis offends paragonimiasis in reason of their flagrant clinicoradiologic similarities, thus often causing the finding of this parasitosis after a long series of investigations; ii) paragonimiasis is not listed in the official registers of illnesses kept by the different African Ministers of Public Health; and iii) owing to the lack of awareness of local health professionals to paragonimiasis, this disease is little evoked in face of a chronic cough simulating pulmonary tuberculosis so that probably several cases of paragonimiasis are long undetected. Two other points are not still well elucidated at the present time. Indeed, parasite identification only based on egg size is difficult to do in reason of variations in egg length and width for each species so that we cannot be totally certain of Paragonimus species indicated in past reports. Contrary to river crabs which are well documented in Africa, few data about molluscs involved in the life cycle of this parasite are currently available.

In view of these above three points, the following questions arose: what was the total number of human cases reported in the literature for the different African countries? What were wild mammal species which could develop a natural infection with Paragonimus spp.? What were local intermediate hosts involved in the life cycle of these parasites? To answer these questions, a retrospective review on paragonimiasis in Africa was carried out by considering papers published during the 20th century and more recently. It included studies made on the different human cases, the animal reservoir as well as snails and crabs which acted in the life cycle of local Paragonimus species.

\section{Methods}

Papers reporting studies made in Africa or in other continents on African nationals and persons who have stayed in Africa were systematically researched. No restriction in the number of patients, the year of study and language of publication was applied.
The documentation was researched by consulting the PubMed data bank or by a detailed examination of references given in the selected papers and particularly in reviews. After reading of each paper, the following data: author(s), country in which the study was carried out, year of publication, population concerned with its characteristics lage, sex, profession) when they are mentioned, circumstances of discovery, eventual complications observed, and concomitance of paragonimiasis with pulmonary tuberculosis, were indexed. Paragonimus species identified and parasite reservoirs, if mentioned, were listed. In each country, results were classed depending on the abundance of scientific production.

In the present paper, African patients were recorded according to the country in which paragonimiasis diagnosis was made. In contrast, when the detection of Paragonimus eggs was carried out on a continent other than Africa, the persons were listed in relation to the African country in which they have stayed or traveled.

\section{Diagnostic and therapy of Paragonimiasis}

To establish a diagnostic of paragonimiasis, epidemiological and clinicoradiological observation must be collected and biological examination be carried out. Majority of people infected with Paragonimus trematodes are asymptomatic. ${ }^{5}$ However, before the appearance of the main symptoms, an initial episode of abdominal pain, diarrhea, urticaria, chills and fever may occur, thus corresponding to the invasion period. ${ }^{6,7}$ In Africa, the most common manifestation is cough $(100 \%){ }^{8}$ The blood-flecked sputum is seen in $86 \%$ of cases, ${ }^{9}$ thoracic pain in $60 \%,{ }^{10}$ and hemoptysis in $43 \%{ }^{11}$ Radiological pictures show nodular infiltration, sometimes pleural fluid and/or cavities. Olympic-ring pictures seen on chest radiographs are pathognomonic of paragonimiasis. Extrapulmonary paragonimiasis, based on the migration of young and mature flukes to other organs may occur, causing sometimes damage in muscle, testes, liver, kidney, spinal cord and brain. ${ }^{5}$ Cerebral paragonimiasis had been suspected in the continent but never proved. Some complications may appear: fibrosis, pachypleuritis, calcifications, right ventricular dilatation, and intracranial calcifications. Hypereosinophilia is seen in most cases. Serological detection using Elisa or haemagglutination tests is possible in Asia, but rare in Africa. To confirm diagnosis, the main investigation to carry out is microscopic examination of stools or sputa to find Paragonimus eggs. ${ }^{12}$ Nowadays, praziquantel (75 $\mathrm{mg} / \mathrm{kg} / \mathrm{d}$ ) is used to treat this disease within two or three days. 


\section{Paragonimiasis and humans}

Figure 1 shows African countries in which reports on human paragonimiasis were published. Apart from two states (Libya, South Africa) in which a few cases were found, the others were detected in ten countries located in the intertropical zone. The total number of papers reported by authors as well that of human cases are chronologically listed on Table 1 for each country. Two states: Nigeria and Cameroon were mainly affected by this disease. Twenty four reports and 1778 cases were recorded for Nigeria, while 17 papers and 454 cases were listed for Cameroon. In the other countries, a total of 63 infected patients were noted in the different papers and the distribution of these cases was scattered.

\section{Nigeria}

Table 2 lists the different studies which were carried out in this country since 1939 . Out of a total of 7105 patients or biological products examined, $25 \%$ were affected by this disease and/or showed the presence of Paragonimus eggs. Two species, i.e., $P$. africanus and $P$. uterobilateralis, were identified in several reports, while the others did not give any information on this point. The most outstanding fact was the occurrence of a paragonimiasis outbreak in the eastern part of Nigeria during the Biafra war (19671970). Owing to the scarcity of food several hundred people had modified their eating habits, particularly by ingesting uncooked crabs. Most patients were children and originated from the region of Okigwi. $P$. uterobilateralis was recognized as the responsible species. $^{15,16,18}$ In $3 \%$ of cases, this disease was associated with tuberculosis. ${ }^{15}$ Since 1974, several papers demonstrated that the neighboring districts of Kiwi and Umuahia in the eastern part of Nigeria were endemic zones for paragonimiasis. According to Sachs and Voelker, ${ }^{31}$ the two factors favoring parasitosis extension were local habits to eat crustaceans and the lack of hygiene of these populations.

In the other districts of eastern Nigeria, some cases of paragonimiasis were also reported. In a survey carried out in the Igwun River basin, Udonsi noted a strong increase of the prevalence (at 16.8\%), particularly in children and adolescents. ${ }^{25}$ In the Cross River basin, Arene et al. noted a similar prevalence for human paragonimiasis $(12.8 \%){ }^{27}$ However, further studies carried out after 2000 in this last basin demonstrated lower prevalence at $8.6 \%$ and $9.6 \% .^{28,29}$

\section{Cameroon}

Table 3 shows the number of Paragonimus-infected patients in different studies made in this country since 1932. In spite of the high figures of persons examined $(11,236)$, only $4 \%$ were infected. The first study was carried out in northwestern Cameroon with the finding of Paragonimus eggs in an 11-yearold child known to be a great consumer of local prawns. $^{32}$ The subsequent surveys were made in other districts, all located in the western and southern parts of Cameroon. However, the prevalence of natural infection ranged from 1.2 to $13.0 \%$ and this finding must be related to the following two factors. First, the lowest values of prevalence (from 1.2 to $4 \%$ ) were noted for samples higher than 1000 people while the others (from 5.6 to $10.6 \%$ ) were found for samples of lower size. Second, this variation also depends on the region in which every survey was made. Indeed, it seems that people living in southern and southwestern districts of Cameroon would be less infected than those inhabiting other regions. As reported for Nigeria, most infected patients were children and adolescents. It is interesting to note here the description of two clinical cases of cerebral paragonimiasis (a third case was suspected).

Out of the three species of Paragonimus indicated in these studies (the presence of $P$. uterobilateralis was only suspected), $P$. africanus was the most frequent species found in Cameroon, at least in studies carried out after 1978.

\section{Other countries}

Table 1 gives, for each country, the number of human cases. In Libya, two cases were reported. The first concerned a 36-year-old patient suspected of cerebral paragonimiasis so that the finding of Paragonimus eggs was fortuitous. Unfortunately, no autopsy was done. ${ }^{37}$ The second was a European who frequently traveled in Cameroon, Ivory Coast and Nigeria for professional reasons. ${ }^{38}$ In Congo, two human cases were listed. The first was an adult living at Matadi (southern Congo) who mainly suffered from chest pain and haemoptysis. No species identification was made on Paragonimus eggs. ${ }^{39}$ Another case was a 16-year-old girl, originating from the northwest of Congo and hospitalised in France for haemoptysis episodes. Paragonimus eggs were found in her bronchial fluid but parasite species was not determined. ${ }^{40}$ In Democratic Republic of Congo, three cases were reported. The first was a 40-yearold man, originating from Katompe and hospitalised for haemoptysis over a 15-month period during which unidentified Paragonimus eggs were found in his sputa. ${ }^{41}$ The second case concerned a soldier showing an abnormal radiological picture. An adult worm of Paragonimus was found during a lobectomy but the bad state of parasite did not allow species identification. $^{42}$ Two decades later, a case was detected in a patient originating from the Kivu province. $P$. africanus eggs were found in his sputa and stools. ${ }^{43}$

In Gambia, four cases were noted in patients originating from Casamance but parasite identification was not provided (Bowesman 1960). ${ }^{13}$ 
In Ivory Coast, the first case was a 36-year-old woman treated for tuberculosis. Paragonimus eggs were found on a lung piece after a lobectomy. ${ }^{44}$ Five infected patients living in the southwestern part of Ivory Coast were reported by Assoa. ${ }^{45}$ Other nine cases in western and southern districts were also listed by Bosse. ${ }^{46}$ In 1988, Paragonimus eggs were observed in the sputa of a woman, originating from the north of the country, who consulted for recurrent haemoptysis episodes. ${ }^{47}$ Several Paragonimus eggs were also found in a bronchial fluid at Abidjan. ${ }^{48}$ In South Africa, several eggs of $P$. kellicotti were noted in the fluid collected from a cyst in a 9-year-old child, hospitalised for tubercular peritonitis. ${ }^{49}$ In Liberia, thirteen cases of human infection with $P$. uterobilateralis were reported in 1979, 1980 and 1987. ${ }^{50,51}$ According to Sachs and Voelker, ${ }^{50}$ three districts, i.e., Lofa, Zorzor and Bong, were endemic zones for paragonimiasis. In 1983, a survey in the Mauwa village demonstrated a prevalence of $7.8 \%$ out of 127 boys and girls examined. ${ }^{52}$ Sachs also reported a case of epilepsy associated to paragonimiasis in a schoolboy. ${ }^{51}$

In Gabon, the first case was the finding of $P$. africanus eggs in the stools of a 4-year- old boy hospitalised for lung infection following his arrival in France. $^{53}$ Three years later, $P$. uterobilateralis eggs were found in the sputa and/or stools of three patients, originating from the Mitoné village. ${ }^{54}$ In 1993, an adult worm and several eggs of $P$. westermani were found in a lung piece after a lobectomy made on a soldier in a context of a recurrent hemoptysis. ${ }^{55}$ Three years later, two adults of $P$. westermani and numerous eggs were seen in the lungs of a 38-year-old patient, originating from the southeast of Gabon. ${ }^{56}$ The last case was an extrapulmonar paragonimiasis diagnosed in a 29year-old white France-living woman who had traveled for the first time in Gabon and showed skin and arthropathy troubles without pulmonary symptoms. $^{57}$ In Equatorial Guinea, the first study concerned five patients detected during a paragonimiasis screening of local population and parasite eggs were identified as $P$. africanus. ${ }^{58}$ The second paper reported the case of a 29-year-old Guinean hospitalised in a Spanish hospital for a longlasting crural hemiparesis. Examination of his sputa revealed the presence of Mycobacterium tuberculosis and unidentified Paragonimus eggs. ${ }^{59}$ In Benin, a single case was described in a 70-year-old woman who complained from chest pain and chronic cough from several decades. Paragonimus eggs were found in her sputa but parasite species was not made. ${ }^{60}$

Table 1. Distribution of human cases of paragonimiasis in African countries

\begin{tabular}{llll}
\hline Country & $\begin{array}{l}\mathbf{N}^{\circ} \text { of } \\
\text { reports/articles }\end{array}$ & $\begin{array}{l}\text { Date of detection } \\
\text { of the first case }\end{array}$ & $\begin{array}{l}\text { Number of positive case } \\
\text { since this date }\end{array}$ \\
\hline Libya & 2 & 1920 & 2 \\
Cameroon & 17 & 1932 & 454 \\
Nigeria & 24 & 1939 & 1,778 \\
Congo & 2 & 1933 & 2 \\
Democratic Republic of Congo & 3 & 1947 & 3 \\
Gambia & 2 & 1965 & 4 \\
Liberia & 13 & 1979 & 25 \\
Ivory Coast & 5 & 1974 & 16 \\
South Africa & 1 & 1975 & 1 \\
Gabon & 5 & 1981 & 7 \\
Equatorial Guinea & 2 & 1991 & 2 \\
Benin & 1 & 1999 & 1 \\
Totals & 71 & - & 2,295 \\
\hline
\end{tabular}

\section{Paragonimus and other vertebrates}

Natural infections were noted in several countries. In Liberia, $P$. uterobilateralis was found in the swamp mongoose (Atilax paludinosus) and the dog. ${ }^{3,61}$ In Nigeria, $P$. uterobilateralis eggs were seen in 26 biological products collected from civets (Viverra civetta). ${ }^{62,63}$ In Cameroon, the black mongoose (Crossarchus obscurus), ${ }^{3}$ the civet, ${ }^{9}$ and the drill (Mandrillus leucophaeus) ${ }^{31}$ were found infected with $P$. africanus. The dog was also identified as a natural host of $P$. uterobilateralis and of Paragonimus $s p p^{13}$,

${ }^{36}$ In Gabon, the white-tailed mongoose (Ichneumia albicauda) was noted as a natural host of $P$. uterobilateralis. $^{54}$ In Ivory Coast, Paragonimus spp eggs were observed in C. obscurus. ${ }^{46}$

\section{Paragonimus and intermediate hosts}

Compared to second intermediate hosts (crustaceans), little information on snails acting as first intermediate hosts in the life-cycle of African Paragonimus is available. The first reports concerned 
the prosobranch Potadoma freethii (Thiaridae) which was found infected by Paragonimus spp in Cameroon $^{13,34}$ and Nigeria. ${ }^{64}$ However, no natural infection was found in numerous $P$. freethii dissected in Cameroon. ${ }^{9}$ Another species was a thiarid and was named as Melania spp in Nigeria. ${ }^{26}$ Moreover, two land snails harbouring microcercous cercariae were cited as first intermediate hosts of Paragonimus spp The first was Homorus striatella (Subulinidae) in Liberia, $^{65,66}$ while the other was an unidentified achatinid in Cameroon. ${ }^{67}$

Several species of freshwater crabs have been reported for their role in the life cycle of Paragonimus spp in Africa (Table 4). Most reports cited two groups of freshwater crabs known to bury holes in the soil (burrow crabs). The first concerns two species belonging to the Liberonautes genus (in Liberia and Ivory Coast) while the second group comprises four species from the Sudanonautes genus (in Nigeria and Cameroon). Another lagoon species; Callinectes marginatus, was also reported in Benin. In Liberia, the prevalence of natural infection with $P$. uterobilateralis ranged from $0.2 \%$ to $95.0 \%$ but these values were dependent of the number of crabs dissected (from 20 to 763). In Ivory Coast, an infection rate of $27.6 \%$ was noted by Bosse for the same crab species. ${ }^{46}$ The results concerning Sudanonautes crabs were different. In Cameroon as well as in Nigeria, greater values of prevalence with Paragonimus spp were noted in reports published before 1980. After this date, the prevalence of crab infection strongly decreased at $6.0 \%$ in Cameroon, ${ }^{10}$ or at $2.4 \%$ in Nigeria. ${ }^{64}$ In the former country, both species of Paragonimus were found for metacercariae, while $P$. uterobilateralis was only noted in Nigerian crabs. Lastly, the prevalence of crab infection in Benin was $5.0 \%{ }^{60}$

Table 2. Distribution of Paragonimus-infected patients found in Nigeria since 1939

\begin{tabular}{|c|c|c|c|}
\hline References & $\begin{array}{l}\text { No. of persons or biological } \\
\text { products examined }\end{array}$ & No. of positive cases (\%) & Paragonimus species \\
\hline Dale $1939^{13}$ & 1 & 1 & \\
\hline Nwokolo ${ }^{15}$ & 5 & 5 & ? \\
\hline Nwokolo ${ }^{16,17}$ & 100 & $100^{a}$ & $?$ \\
\hline Voelker and Nwokolo ${ }^{18}$ & 69 & 69 & P. africanus \\
\hline Oelerich and Nwokolo ${ }^{20}$ & 27 & 27 & P. uterobilateralis \\
\hline Nwokolo and Volkmer ${ }^{21}$ & 111 & 111 & ? \\
\hline Grillo et al. $^{22}$ & 1 & $1^{b}$ & $?$ \\
\hline Onuigbo and Nwako ${ }^{23}$ & 1 & $1^{c}$ & P. uterobilateralis \\
\hline Oyediran et al. ${ }^{24}$ & 3 & 3 & ? \\
\hline Ibanga and Eyo ${ }^{28}$ & 2,209 & $192(8.6)$ & P. uterobilateralis \\
\hline Ibanga et al. ${ }^{29}$ & 1,100 & $203^{d}(9.3)$ & ? \\
\hline Asor et al. ${ }^{30}$ & 120 & 120 & $?$ \\
\hline Totals & 7,105 & $1778(25.0)$ & ? \\
\hline
\end{tabular}

Table 3. Distribution of Paragonimus-infected patients in Cameroon since 1932

\begin{tabular}{|c|c|c|c|}
\hline References & $\begin{array}{l}\text { No. of persons or biological } \\
\text { products examined }\end{array}$ & $\begin{array}{l}\text { No. of positive cases } \\
(\%)\end{array}$ & $\begin{array}{l}\text { Paragonimus } \\
\text { species }\end{array}$ \\
\hline Libert $^{32}$ & 1 & 1 & $?$ \\
\hline Cannon $1949^{13}$ & 1 & 1 & ? \\
\hline Zahra $^{33}$ & 3,002 & $120^{\mathrm{a}}(4)$ & P. westermani \\
\hline Vogel and Crewe ${ }^{13}$ & 256 & $27(10.6)$ & P. westermani \\
\hline Timsit $^{34}$ & 150 & $19^{\mathrm{b}}(13)$ & P. africanus \\
\hline Ripert et al. ${ }^{9}$ & 2,097 & $119^{c}(2.0)$ & P. africanus \\
\hline Kum and Nchinda ${ }^{8}$ & 900 & $50(5.6)$ & P. africanus \\
\hline Sam-Abbenyi ${ }^{35}$ & 2,826 & $35(1.2)$ & $?^{d}$ \\
\hline Ollivier et al. ${ }^{36}$ & 212 & $14(6.6)$ & $?$ \\
\hline $\begin{array}{l}\text { Moyou-Somo and Tagni- } \\
\text { Zukam }^{11}\end{array}$ & 309 & $30(9.6)$ & P. africanus \\
\hline Moyou-Somo et al. ${ }^{10}$ & 1,482 & $38(2.5)$ & P. africanus \\
\hline Totals & 11,236 & $454(4.0 \%)$ & - \\
\hline
\end{tabular}


Table 4. Species of crabs found in Africa and the prevalence of natural infection with Paragonimus spp Abbreviations: L. (Liberonautes). P. (Paragonimus). S. (Sudanonautes)

\begin{tabular}{|c|c|c|}
\hline Country and references & $\begin{array}{l}\text { Crab species } \\
\text { (number of crabs dissected) }\end{array}$ & $\begin{array}{l}\text { Paragonimus metacercariae } \\
\text { (prevalence of crab infection) }\end{array}$ \\
\hline \multicolumn{3}{|l|}{ Cameroon } \\
\hline Vogel and Crewe ${ }^{13}$ & S. africanus (110), S. peli ${ }^{\mathrm{a}}(90)$ & P. africanus (?) \\
\hline Voelker and Sachs ${ }^{68}$ & S. africanus (121), S. aubryi (16), & P. africanus (47.9\%), P. uterobi- \\
\hline Timsit $^{34}$ & S. pelii ${ }^{\text {a }}(32)$ & lateralis (11.2\%), both (10\%) ${ }^{\mathrm{b}}$ \\
\hline Ripert et al. ${ }^{9}$ & S. africanus (?) & Species not given $(>80 \%)$ \\
\hline Ollivier et al. ${ }^{36}$ & Sudanonautes spp (11) & Species not given $(9.1 \%)$ \\
\hline \multirow[t]{3}{*}{ Moyou-Somo et al. ${ }^{10}$} & S. africanus (707), S. aubryi ${ }^{\text {a }}(50)$, & Species not given $(13.2 \%)^{b}$ \\
\hline & S. granulatus (37) & Species not given $(6.0 \%)$ \\
\hline & S. africanus (85) & \\
\hline \multirow{7}{*}{$\begin{array}{l}\text { Nigeria } \\
\text { Voelker and Nwokolo }{ }^{18} \\
\text { Voelker and Sachs }{ }^{68} \\
\text { Udonsi } \\
\text { Arene et al. }\end{array}$} & S. africanus + S. aubryi ${ }^{\mathrm{a}}(45)$ & P uterobilateralis (100\%) (15\%) \\
\hline & S. africanus (11) & P. uterobilateralls (100\%) (1.5\%) \\
\hline & S. africanus (223), & P. uterobilateralis (61.4\%) \\
\hline & S. aubryi ${ }^{\mathrm{a}}(117)$ & P. uterobilateralis (79.5\%) \\
\hline & S. africanus + S. aubryi ${ }^{\text {a }}(163)$ & P. uterobilateralls (93.8\%) \\
\hline & Sudanonautes spp. (?) & Species not given (3.0\%-13.0\%) \\
\hline & S. africanus $(1,200)$ & P. uterobilateralıs (2.4\%) \\
\hline 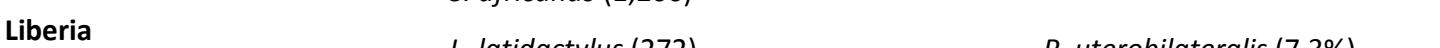 & L. latidactylus (272) & P. uterobilateralis $(7.3 \%)$ \\
\hline Sachs et al. ${ }^{69}$ & L. latidactylus (214) & P. uterobilateralis $(0.9 \%)$ \\
\hline Sachs and Cumberlidge ${ }^{70}$ & L. latidactylus (20) & P. uterobilateralis (95.0\%) \\
\hline $\begin{array}{l}\text { Sachs and Cumberlidge } \\
\text { Sachs and Cumberlidge }\end{array}$ & L. latidactylus nanoïdes (763) & P. uterobilateralis $(0.2 \%)$ \\
\hline $\begin{array}{l}\text { Benin } \\
\quad \text { Aka et al. }\end{array}$ & Callinectes marginatus (176) & Species not given (5\%) \\
\hline $\begin{array}{l}\text { Ivory Coast } \\
\text { Bosse }^{46}\end{array}$ & L. lactidactylus (47) & Species not given (27.6\%) \\
\hline
\end{tabular}

Figure 1. Geographical location of African countries in which cases of human paragonimiasis were detected from the $X X^{\text {th }}$ century (1 Libya, 2 Cameroon, 3 Nigeria, 4 Congo, 5 Democratic Republic of Congo, 6 Gambia, 7 Liberia, 8 Ivory Coast, 9 South Africa, 10 Gabon, 11 Equatorial Guinea)

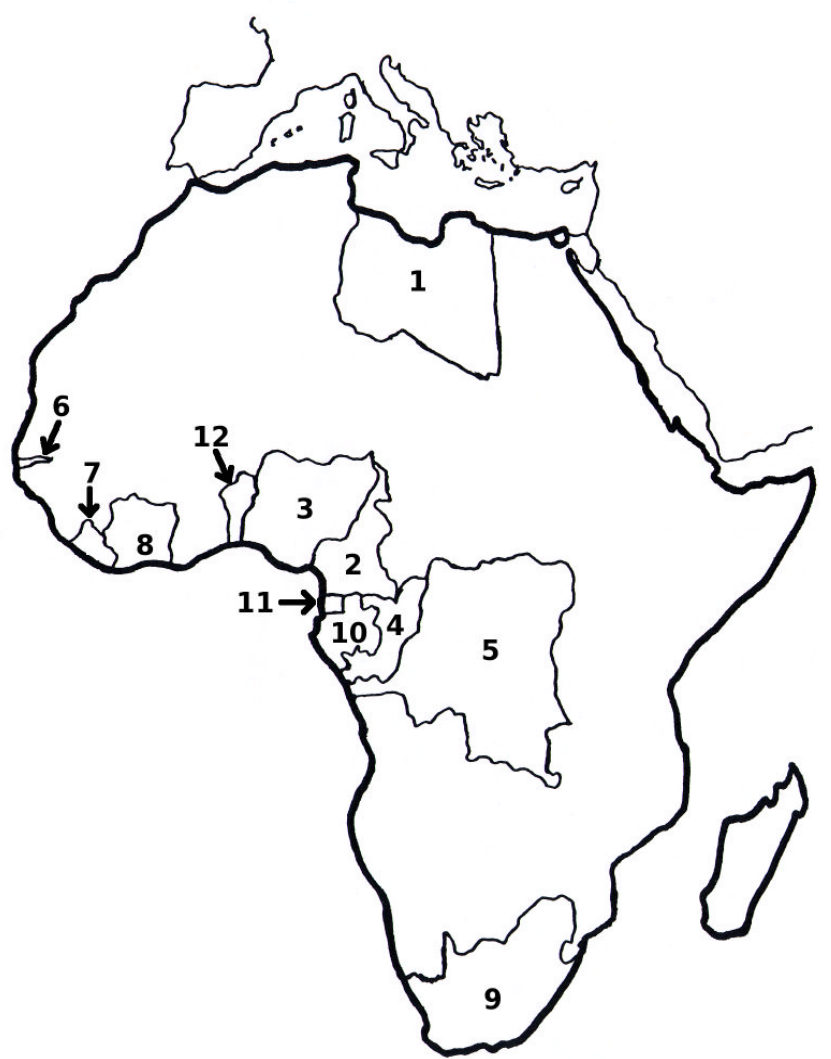




\section{Discussion}

In Africa, apart from the three cases recorded in Libya and South Africa, the majority of the other patients were originating from countries geographically located in the intertropical zone. A few persons were contaminated by the parasite during their travel in this endemic zone. Two main regions: West Africa and Central Africa can be identified. These findings agreed with data currently known on African paragonimiasis (see reviews by Brown $^{73}$ and Ripert ${ }^{74}$ ). As shown in Table 2, the highest prevalence of paragonimiasis over the past fifty years was noted in Nigeria. If $45.7 \%$ of cases were listed during the Biafra civil war and in the years following it, the other patients were recorded during the past 25 years with lower infection rates (from 8.6 to $16.8 \%$ ). In other African countries, human cases of paragonimiasis were less numerous: only $4 \%$ in Cameroon and a few cases in the other states of the intertropical zone. To explain these results, two hypotheses might be proposed. The first would be to admit that paragonimiasis would be more studied in Nigeria and Cameroon than in other countries and this is supported by the number of papers listed in Table 1 for Nigeria and Cameroon during the same period. The second assumption would be to consider eastern Nigeria and Cameroon as main endemic zones for human paragonimiasis, while the other countries would be only accessorily endemic, as least in one or several districts. One may even wonder if there is not a continuum of paragonimiasis in these two countries with spatial extensions in other bordering countries, probably related to crab selling which is well developed along the Guinea Gulf. To verify these hypotheses, further screenings are necessary to determine the exact prevalence of human paragonimiasis in countries other than Nigeria and Cameroon by recruiting people who suffered from chronic cough, haemoptysis and/or epilepsy, and by carrying out sputum and/or stool examination, or some serological tests.

In most reports, the main species found in Africa were $P$. africanus and $P$. uterobilateralis (Tables 2, 3 and 4). According to Cabaret et al., ${ }^{4}$ the fresh eggs of the former species were high-sized (a mean of $91 \times 49 \mu \mathrm{m}$ ) while those of $P$. uterobilateralis were of smaller dimensions $(69 \times 42 \mu \mathrm{m})$. As most authors listed in this review have identified Paragonimus species using eggs fixed in variable concentrations of formalin, one may wonder if the concentration of this fixative did not have an effect on egg morphology. As Cabaret et al. had identified other two species of Paragonimidae in their report, ${ }^{4}$ it seems difficult, under these conditions, to recognize the species of African Paragonimus only by measuring formalinfixed eggs and perhaps fresh eggs, as already suggested by Blair et al. ${ }^{1}$ However, another explanation cannot be excluded, as the diploid or triploid status of a $P$. westermani population had an effect on egg sizes. ${ }^{1}$

The animal reservoir was mainly constituted by crab-eating mammals such as civets, mongooses, mandrills and dogs. However, other mammals such as monkeys, mouse, rats and shrews can develop a Paragonimus infection when experimentally infected. ${ }^{1}$ According to Voelker et al., ${ }^{63}$ the Muridae family would not represent an important reservoir of Paragonimus parasites. However, mammals might be contaminated by other paragonimid species such as $P$. suis in pigs. ${ }^{75}$

In spite of investigations on African snails able to sustain the larval development of Paragonimus spp, the identity of the host snail remains doubtful. According to several authors, 13,26,34,63 the intermediate host was a prosobranch, whereas it belonged to a land species for Sachs and Cumberlidge $^{65,}{ }^{66}$ and Moyou-Somo and Simo. ${ }^{67}$ Several hypotheses to explain this discrepancy might be proposed. The first was to consider the food of river crabs, as they are able to move about a long distance and can eat land invertebrates as well as freshwater snails. But this assumption is contested by Brown ${ }^{73}$ in reason of the finding of Paragonimus metacercariae in crabs which did never leave large rivers. $^{76}$ The second hypothesis was the fact that each paragonimid species might use a single snail species for the development of its larval forms, while the third would be the possibility of a large scale of snail species as intermediate hosts for $P$. africanus and $P$. uterobilateralis in Africa. Experimental studies are still necessary to elucidate the problem of snail species in the life cycle of African Paragonimus.

Contrary to crustacean species which were identified as intermediate hosts of Paragonimus spp on the Asian continent, ${ }^{1}$ only river crabs were recognized in West and Central Africa. In addition to crabs belonging to Liberonautes and Sudanonautes genera which were the main intermediate hosts in Cameroon, Liberia and Nigeria, another crab species: Callinectes marginatus, was also cited in Benin. ${ }^{60}$ This last finding demonstrates that metacercaria-carrying crabs are not limited to the abovementioned first two genera and other species may be still discovered as intermediate hosts of African Paragonimus. In spite of serial surveys carried out in Africa in the past five decades, a progressive decrease in the prevalence of crab infection was noted and this finding is difficult to interpret. The current change of eating habits of local people with giving up of crab consumption by the youngest classes and the health promotion policy might be the first explanation so that the decrease of prevalence noted in crabs would be an indirect consequence. However, another hypothesis involving the extension of surveys on crabs in zones other than those in which infected patients were detected cannot be excluded.

In conclusion, two main countries, i.e., Cameroon 
and Nigeria, were currently affected by human paragonimiasis, while the distribution of human cases in the other eight states of the intertropical zone was scattered. Infected patients were currently few in number and two Paragonimus species were detected. An uncertainty still exists on the relationship between parasite and snail identity involved in paragonimiasis. Seven crab species belonging to Callinectes, Liberonautes and Sudanonautes genera are known to harbour paragonimid metacercariae and several are able to keep both Paragonimus species in their organs. Due to the situation described above, one may even wonder if it is efficient to still develop wide-scale screenings of paragonimiasis in local populations when we consider the cost necessary for such investigations. It would be more realistic to revise our current position. In our opinion, the best choice would be to do paragonimiasis detection in antituberculosis centers and to train laboratory technicians for detecting simultaneously the presence of mycobacteria and/or paragonimid eggs during the same sputum examination. Finally, it is interesting to remind that human paragonimiasis is a current parasitic disease which must be evoked in face of a chronic cough difficult to cure in people living in an endemic zone.

\section{Acknowledgments}

The authors are grateful to Pr. D. Blair and Dr A. SamAbbenyi for numerous articles they sent to N.A. Aka. They are also grateful to the Library of the Institute of Tropical Medicine, Antwerp, the Netherlands, and the BernhardNocht-Institut für Schiffs-und Tropenkrankheiten Bibliothek, Hamburg, Germany, for their contribution.

\section{References}

1. Blair D, Xu ZB, Agatsuma T. Paragonimiasis and the genus Paragonimus. Adv Parasitol. 1999; 42:113-22.

2. Toscano C, Hai YS, Nunn P, Mott KE. Paragonimiasis and tuberculosis, diagnostic confusion: a review of the literature. Trop Dis Bull. 1995; 92:R1-R27.

3. Voelker J, Vogel H. Zwei neue ParagonimusArten aus West-Afrika: Paragonimus africanus und Paragonimus uterobilateralis (Troglotrematidae; Trematoda). Z Tropenmed Parasitol. 1965; 16:125-148.

4. Cabaret J, Bayssade-Dufour C, Tami G, Albaret JL. Identification of African Paragonimidae by multivariate analysis of the eggs. Acta Trop. 1999; 72:79-89.

5. Khilnani GC. paragonimiasis (lung fluke). Chapter 21b. In: Respiratory medicine in the tropics, by
Pande JN (Editor). Oxford: University Press, 1998:284-5.

6. Malek EA. Snail-transmitted parasitic diseases. Boca Raton: CRC Press, 1980.

7. Harinasuta T, Pungpak S, Keystone JS. Trematode infections: opisthorchiasis, clonorchiasis, fascioliasis and paragonimiasis. Infect Dis Clin North Am. 1993; 7:699-716.

8. Kum PN, Nchinda TC. Pulmonary paragonimiasis in Cameroon. Trans R Soc Trop Med Hyg. 1982; 76:768-772.

9. Ripert C, Carrie J, Ambroise-Thomas P, Baecher R, Kum NP, Same-Ekobo A. Epidemiologic and clinical study of paragonimiasis in Cameroon. Results of niclofolan treatment. Bull Soc Pathol Exot Filiales. 1981; 74:197-206.

10. Moyou-Somo R, Kefie-Arrey C, Dreyfuss G, Dumas M. An epidemiological study of pleuropulmonary paragonimiasis among pupils in the peri-urban zone of Kumba town, Meme Division, Cameroon. BMC Public Health. 2003; 3:40.

11. Moyou-Somo R, Tagni-Zukam D. Paragonimiasis in Cameroon: clinicoradiologic features and treatment outcome. Med Trop. 2003; 63:163167.

12. Nozais JP, Datry A, Danis M. Traité de Parasitologie Médicale. Paris: Pradel Editions, 1996.

13. Vogel $H$, Crewe $W$. Beobachtungen über die Lungenegel-Infektion in Kamerun (WestAfrika). Z Tropenmed Parasitol. 1965; 16:109-125.

14. Yarwood GR, Elmes BGT. Paragonimus cyst in a West African native. Trans R Soc Trop Med Hyg. 1943; 36:347-351.

15. Nwokolo C. Paragonimisasis in eastern Nigeria. J Trop Med Hyg. 1964; 67:1-4.

16. Nwokolo C. Outbreak of paragonimiasis in Eastern Nigeria. Lancet. 1972; 1:32-33.

17. Nwokolo C. Endemic paragonimiasis in eastern Nigeria. Clinical features and epidemiology of the recent outbreak following the Nigerian civil war. Trop Geogr Med. 1972; 24:138-147.

18. Voelker J, Nwokolo C. Human paragonimiasis in eastern Nigeria caused by Paragonimus uterobilateralis. Z Tropenmed Parasitol. 1973; 24:323-328.

19. Nwokolo C. Endemic paragonimiasis in Africa. Bull World Health Organ. 1974; 50:569-571.

20. Nwokolo C, Volkmer KJ. Single dose therapy of paragonimiasis with menichlopholan. Am J Trop Med Hyg. 1977; 26:688-692.

21. Oelerich S, Nwokolo C. Serologische Untersuchungen mit Paragonimus uterobilateralis- und anderen TrematodenAntigenen an Seren von ParagonimiasisPatienten aus Nigeria. Trop Med Parasitol. 1974; 25:137-146. 
22. Grillo IA, Abioye AA, Oni SB. Pulmonary paragonimiasis simulating bronchogenic carcinoma. J Trop Med Hyg. 1973; 76:75-77. Onuigbo WIB, Nwako FA. Discovery of adult parasites of Paragonimus uterobilateralis in human tissue in Nigeria. Tropenmed Parasitol. 1974; 25:433-6.

23. Oyediran $A B O O$, Fajemisin $A A$, Abioye $A A$, Lagundoye $S B$, Olugbile $A O B$. Infection of the mastoid bone with a Paragonimus-like trematode. Am J Trop Med Hyg. 1975; 24:268273.

24. Demetriou A, Phillips BM, Hendrickse RG. A case of paragonimiasis. Arch Dis Child. 1978; 53:912913.

25. Udonsi JK. Clinical field trials of praziquantel in pulmonary paragonimiasis due to Paragonimus uterobilateralis in endemic populations of the Igwun Basin, Nigeria. Trop Med Parasitol. 1989; 40:65-68.

26. Arene FOI, Ibanga E, Asor JE. Epidemiology of paragonimiasis in Cross River basin, Nigeria: prevalence and intensity of infection due to Paragonimus uterobilateralis. Public Health. 1998; 112:119-122.

27. Ibanga ES, Eyo VM. Pulmonary paragonimiasis in Oban community in Akamkpa Local Government area, Cross River State, Nigeria: prevalence and intensity of infection. Trans R Soc Trop Med Hyg. 2001; 95:159-160.

28. Ibanga ES, Arene FOI, Asor JE. Association of pulmonary paragonimiasis with active pulmonary tuberculosis in rural Yakurr community in Cross River Basin, Nigeria. Mary Slessor Journal of Medicine. 2003; 3:19-23.

29. Asor JE, Ibanga SE, Arene FOI. Paragonimus uterobilateralis: peak period of egg output in sputum of infected subjects in Cross River basin, Nigeria. Mary Slessor Journal of Medicine. 2003; 3:24-27.

30. Sachs R, Voelker J. A primate, Mandrillus leucophaeus, as natural host of the African lung fluke Paragonimus africanus in West-Cameroon. Tropenmed Parasitol. 1975; 26:205-6.

31. Libert C. A case of paragonimiasis. West Afr Med J. 1932;5:51-52.

32. Zahra A. Paragonimiasis in the southern Cameroon: a preliminary report. West Afr Med J. 1952; 25:75-82.

33. Timsit P. La paragonimose pulmonaire au Cameroun. Med Trop (Mars). 1978; 38:287-297.

34. Sam-Abbenyi A. Endemic pulmonary paragonimiasis in Lower Mundani (Fontem district of southwest Cameroon). Results of treatment with praziquantel. Bull Soc Pathol Exot Filiales. 1985; 78:334-341.

35. Ollivier G, Boussinesq M, Albaret JL, et al. Etude épidémiologique d'une distomatose à
Paragonimus sp. au Sud-Cameroun. Bull Soc Pathol Exot. 1995; 88:164-169.

36. Onorato R. La paragonimiasi in Tripolitania. Arch Ital Sc Med Col. 1920; 1:1-13.

37. Fossati C. Sulle parassitosi dell'apparato respiratorio. Rev Iber Parasitol. 1971;31:213-232.

38. Van Hoof L. Un cas de distomatose pulmonaire au Congo. Ann Soc Belg Med Trop. 1933; 13:473478.

39. N'Dzossi A. Observations clinique et épidémiologique du premier cas de paragonimose humaine au Congo-Brazzaville. Bordeaux: MD thesis, 2000.

40. Bertrand J. Distomatose pulmonaire ou hémoptysie pulmonaire à Paragonimus. Ann Soc Belg Med Trop. 1947; 27:1-4.

41. Darras T, Fain A, Moens E, Robberechts W, Seghers K, Vandepitte J. Een nieuw Congolees geval van longparagonimose. Ann Soc Belg Med Trop. 1960; 40:725-731.

42. Dierckx P, Coigneau $H$, Debondt $R$, Leblanc $G$. Paragonimose pulmonaire. Ann Soc Belg Med Trop. 1980; 60:111.

43. Coulibaly N, Cornet L, Doucet J, Loubière R. Paragonimose pulmonaire associée à une bilharziose en République de. Côte d'Ivoire. Nouv Presse Med. 1975; 4:886.

44. Assoa A. Contribution à l'étude de la paragonimose en Afrique: à propos des cinq premiers cas diagnostiqués en Côte d'ivoire. Strasbourg: MD thesis, 1977.

45. Bosse D. Endémicité et parasitose autochtones en Afrique noire: à propos d'un foyer insolite de distomatose pulmonaire en Côte d'Ivoire. Montpellier: PhD thesis, 1984.

46. Aka K, Tchamra M, Fadiga D, Yapi A. Paragonimose pulmonaire: une cause d'hémoptysie. Afr Bio Med. 1995; 1:29-31.

47. Adou-Bryn K, Ouhon J, Assoumou A, Kassi E, Koné $M$, Therizol-Fleury $M$. Champignons et parasites isolés dans 142 liquides d'aspiration bronchiques à Abidjan (Côte d'ivoire). Med Afr Noire. 1999; 46:362-365.

48. McCallum S. Ova of the lung fluke Paragonimus kellicotti in fluid from a cyst. Acta Cytol. 1975; 3:279-280.

49. Sachs R, Voelker J. Human paragonimiasis caused by Paragonimus uterobilateralis in Liberia and Guinea, West Africa. Trop Med Parasitol. 1982; 33:15-16.

50. Sachs R. Occurrence of human lung fluke infection in an endemic area in Liberia. In: Helminth Zoonoses, by Geerts S, Kumar V, Brandt J. (Editors). Dordrecht: Martinus Nijhoff Publishers, 1987:133-7.

51. Sachs R, Albiez EJ, Voelker J. Prevalence of Paragonimus uterobilateralis infection in children in a Liberian village. Trans $\mathrm{R}$ Soc Trop 
Med Hyg. 1986; 80:800-801.

52. Petavy AF, Cambon M, Demeocq F, Dechelotte $P$. A Gabonese case of paragonimiasis in a child. Bull Soc Pathol Exot Filiales. 1981; 74:193-197.

53. Sachs R, Kern P, Voelker J. Paragonimus uterobilateralis as the cause of 3 cases of human paragonimiasis in Gabon. Trop Med Parasitol. 1983; 34:105-108.

54. Boguikouma JB, Moussavou-Kombila JB, OndoNdong F, M'Vou-Yaloula R, Mabicka B, Kombila MJ. Un cas gabonais de paragonimose pulmonaire. Med Afr Noire. 1997; 44:1-2.

55. Vuong PN, Bayssade-Dufour C, Maboka B, Agoula-Gerbeix S, Kombila M. Paragonimus westermani pulmonary distomatosis in Gabon. First case. Presse Med. 1996; 25:1084-1085.

56. Malvy D, Ezzedine KH, Receveur MC, Pistone T, Mercié $P$, Longy-Boursier $M$. Extra-pulmonary paragonimiasis with unusual arthritis and cutaneous features among a tourist returning from Gabon. Travel Med Infect Dis. 2006; 4:340342.

57. Simarro PP, Alamo A, Sima FO, Roche J, Mir M, Ndong $P$. Endemic human paragonimiasis in Equatorial Guinea. Detection of the existence of endemic human paragonimiasis in Equatorial Guinea as a result of an integrated sanitary programme. Trop Geogr Med. 1991; 43:326-328.

58. Ananos G, Trilla A, Graus F, Mas J, Corachan M, Soriano E. Paragonimiasis and pulmonary tuberculosis. Med Clin (Barc). 1992; 98:257-259.

59. Aka NA, Allabi AC, Dreyfuss G, et al. Observations épidémiologiques sur le premier cas de paragonimose humaine et les hôtes intermédiaires potentiels de Paragonimus sp. au Bénin. Bull Soc Pathol Exot. 1999; 92:191-194.

60. Sachs $R$, Cumberlidge $N$. The dog as natural reservoir host for Paragonimus uterobilateralis in Liberia, West Africa. Ann Trop Med Parasitol. 1990; 84:101-102.

61. Voelker J, Sachs R. Observations on the life history of Paragonimus uterobilateralis: the African civet (Viverra civetta) as natural reservoir in Nigeria. Proc ICOPA III, München, 1974; 1:52930.

62. Voelker J, Sachs R, Volkmer KJ, Braband H. On the epidemiology of paragonimiasis in man and in animals in Nigeria, West Africa. Vet Med Rev. 1975; 1-2:161-175.

63. Arene FOI, Ibanga ES, Asor JE. Freshwater snail and crab intermediate hosts of Paragonimus species in two rural communities in Cross River basin, Nigeria. Global Journal of Pure and Applied Science. 1999; 5:184-187.
64. Sachs $R$, Cumberlidge $N$. Isolation of microcercous cercariae from snails caught in an endemic focus of Paragonimus uterobilateralis in Liberia, West Africa. Trop Med Parasitol. 1989; 40:69-72.

65. Sachs R, Cumberlidge N. Notes on the ecology of Homorus striatellus (Rang, 1831), snail host of microcercous cercariae in Liberia, West Africa. Z Angew Zool. 1991; 78:45-53.

66. Moyou-Somo R, Simo GG. Paragonimiasis in southwest Cameroon: isolation of microcercous cercariae from land snails caught in a Paragonimus africanus endemic zone. Wild Environ Med. 1995; 6:44-47.

67. Voelker J, Sachs R. Uber die Verbreitung von Lungenegeln (Paragonimus africanus und $P$. uterobilateralis) in West-Kamerun und OstNigeria auf Grund von Untersuchungen an Süsswasserkrabben auf Befall mit Metacercarien. Trop Med Parasitol. 1977; 28:129-133.

68. Sachs R, Jarrett B, Attia B. Paragonimiasis and tuberculosis in the Bong area. Annual Report 1985, Liberia Research Unit of the Tropical Institute Hamburg 1985: 43-9.

69. Sachs R, Cumberlidge N. A focus of paragonimiasis in Nimba county, Liberia. J Lib Med Dent Ass. 1988; 17:29-40.

70. Sachs R, Cumberlidge N. The dwarf river crab Liberonautes latidactylus nanoides Cumberlidge \& Sachs, 1989, from Liberia -a new second intermediate host of Paragonimus uterobilateralis. Trop Med Parasitol. 1991; 42:7374.

71. Cumberlidge N. Identification of Sudanonautes aubryi (H. Milne-Edwards, 1853) (Brachyura: Potamoidea: Potamonautidae) from West and Central Africa. Z Angew Zool. 1994; 80:225-241.

72. Brown DS. Freshwater snails of Africa and their medical importance. Taylor \& Francis, London, 1994.

73. Ripert C. Distomatoses pulmonaires. In: Ripert C (Ed). Epidémiologie des maladies parasitaires. Tome 2: Helminthoses. Editions Médicales Internationales, Cachan, 1996:148-64.

74. Permin A, Yelifari L, Bloch P, Steenhard N, Hansen NP, Nansen P. Parasites in cross-bred pigs in the Upper East region of Ghana. Vet Parasitol. 1999; 87:63-71.

75. Sachs $R$, Cumberlidge N. First record of the spiny river crab, Liberonautes chaperi (A. MilneEdwards 1887), as second intermediate host of Paragonimus uterobilateralis in Liberia. Ann Trop Med Parasitol. 1991; 85:471-472. 